\title{
OPERATION OF INDEPENDENTS UNDER THE RATE REGULATORY PATTERN
}

\author{
HENRY S. MOSER*
}

I

INTRODUCTION

To comprehend fully the problems of independent insurers under the present rating laws, it is necessary to have a clear appreciation and understanding of the purposes and philosophy of the statutes. An effort will therefore be made in this article to bring into focus the causes of state concern over uncontrolled rating activities and to trace briefly the development of the imposition of state controls over insurance rates. A general summary will be made of the pattern of insurance rate regulation before and after the enactment of the McCarran Act.

The author will then address himself to two basic and intimately related problems of insurance rate regulation. First, how to determine, particularly with regard to independent companies, whether filed rates satisfy the statutory requirement that they be neither "excessive" nor "inadequate"; and, second, what supporting informa. tion is necessary to justify the use of such rates. No attempt will be made to deal with the problem of unfairly discriminatory rates.

Solutions of insurance regulatory problems will more likely be right if it is remembered that rate regulation in the United States has not been confined to insurance, and if the supervisory authorities avail themselves of the experience in other fields. When problems fundamental to rate regulation generally are involved, the writer has attempted to treat them as such. Where the problems are peculiar to competitive rate regulation as distinguished from monopolistic rate regulation, an attempt has been made to draw helpful analogies from principles applied by the Interstate Commerce Commission in regulation of rates of public carriers.

II

Causes and Developarent of State Controls over Fire Insurance Rates

Providing an environment of free and open competition in insurance was once the prevailing state legislative policy in the United States. Between 1885 and I9I2 no fewer than twenty-three states passed anti-compact laws forbidding the creation of insurance combinations having for their purpose the fixing of fire insurance rates. ${ }^{1}$

- LL.B. I921, John Marshall Law School. Member of the Chicago bar. General Attorney, Allstate Insurance Company. Chairman, Section on Insurance Law, American Bar Association I944-1945; Chairman, Section on Insurance Law, Illinois State Bar Association, 1936-1938; President, National Association of Independent Insurers, 1945-1946. The author acknowledges the valuable assistance of Robert S. Morris, member of the Chicago bar, J.D. I948, Northwestern University.

${ }^{1}$ United States v. South-Eastern Underwriters Association, 322 U. S. 533, 555 n. 43 (1944). 
In states not having such statutes, dissolution of fire insurance boards and rating bureaus was sometimes sought by the state on the theory that such organizations constituted combinations in restraint of trade in violation of the common law. ${ }^{2}$

This hostility toward company combinations, and the legislative policy of requiring open competition in fire insurance, gradually gave way to the view that concerted activities should be permitted but regulated. The state of New York took the lead in espousing this approach. It first recognized the legality of fire underwriters boards in $1867 .^{3}$ It was not, however, until I9II that the New York legislature undertook to clothe their insurance superintendent with the power to supervise the activities of fire insurance rating bureaus. ${ }^{4}$

The inauguration of this statutory control was responsive to a recommendation by a joint committee of the Senate and Assembly of New York who had, in the same year, examined the alleged "corrupt practices in connection with legislation and the affairs of insurance companies, other than those doing life insurance business." This committee reached the conclusion that the anti-compact approach was a failure and that joint action in making rates was essential. ${ }^{\circ}$ They found that unrestricted competition invited rate wars, which resulted in the use of discriminatory rates and a dangerous lowering of the quality of protection afforded by insurers.

The immediate cause of the ineffectiveness of the anti-compact laws was the case with which they were evaded by use of independent bureaus promulgating "advisory" rates. ${ }^{8}$ From the point of view of the companies, resort to this device was necessary because fire rates could not safely nor economically be made alone. But when the companies were deprived of the power to combine, they were also deprived of the power to police their competitive activities. Competitive abuses in the form of rate wars, bidding up of commissions, and discriminatory rates were perhaps compounded as a result. ${ }^{9}$ In any case, the evils did exist, and they were not corrected by state antitrust laws.

In I914, the National Convention of Insurance Commissioners received a report from its Committee on Fire Insurance Rates and Rate Making which also recognized the failure of the anti-compact laws to bring about open competition. ${ }^{10}$ This

${ }^{2}$ McCarter v. Firemen's Insurance Co., 74 N. J. Eq. 372, 73 Atl. 80 (Ct. Err. \& App. 1909) (fire insurance companies enjoined from acting under an agreement vesting in the Newark Fire Insurance Exchange the power to fix rates for member companies); Continental Insurance Co. v. Fire Underwriters of the Pacific, 67 Fed. 3ro (C.C.N.D.Cal. 1895) (regulating rates of members of Board a lawful trade purpose; price fixing activities not enjoinable at suit of non-member company); Queen Insurance $C$. v. State, 86 Tex. 250, 24 S.W. 397 (I893) (rate fixing not illegal at common law); Liverpool \& London \& Globe Insurance Co. v. Clunie, 88 Fed. I60 (C.C.N.D.Cal. I898) (held, insurance commissioncr had no power to revoke certificate of authority of company because of its membership in an allegedly illegal combination to raise rates).

${ }^{3}$ E. W. Patterson, The Insurance Commissioner in the Unitred States 274 n. (1927).

Ibid.

- Report of Merritt Committee, Assembly Doc. No. 30 r34th Sess. (igxi).

'Id. at 42 .

${ }^{8}$ Id. at 43. See also National Union Fire Insurance Co. v. Dickinson, I28 Ark. 367, I94 S.W. 254 (1917).

${ }^{\circ}$ See C. A. Kulp, Casualty Insurance 623 (Rev. ed. 1942).

${ }^{10}$ Proceedings of the National Convention of Insurance Commissioners 20 (1915). 
Committee went further, however, than did the New York legislative group. They recommended passage of legislation recognizing and regulating rating bureaus, and prohibiting discriminatory rates. ${ }^{11}$ The passage of laws making membership or cooperation in public rating bureaus compulsory was also urged. ${ }^{12}$

These recommendations were not dispositive of the principal complaint which gave rise to the anti-compact laws, namely, the power of company combinations to charge excessive rates. ${ }^{13}$ The compulsory combination which the committee proposed would have tended to eliminate discriminatory and inadequate rates, but would have suppressed competition and enhanced the problem of monopoly control.

But it must be remembered that it was not until this same year of 1914 that the states first found themselves clearly possessed with the power to control rates. ${ }^{14}$ For it was in that year that the Supreme Court, in German Alliance Ins. Co. v. Lewis, ${ }^{15}$ expanded the concept of "affected with a public interest" to give the states regulatory power over insurance rates. That case arose from a challenge to a blanket rate reduction order of the Kansas Insurance Superintendent, directed at the uniform rates of company members of the fire insurance rating bureau in that state. $^{16}$

Following the lead of Kansas and New York, most of the states in the period between Igr $_{4}$ and I944 undertook to recognize and supervise the activities of fire rating bureaus, and to give their insurance supervisory officials the power to require reasonable rates. ${ }^{17}$ Frequently this reasonableness standard was spelled out to require that rates be neither inadequate, discriminatory, nor excessive. ${ }^{18}$ Under statutes making underwriting profits a factor to be considered by the commissioner in determining whether rates met the rating standards, the test for determining

${ }^{21}$ Id. at $19-21$.

${ }^{21}$ Ibid. For list of states enacting these bills, see National Union Fire Insurance Co. v. Dickinson, 228 Ark. 367 , 194 S.W. 254 (1917).

${ }^{28}$ See German Alliance Insurance Co. v. Lewis, 233 U. S. 389, 416 (1914); German Alliance Insurance Co. v. Hale, 219 U. S. 307, 316 (xgII); Citizens Insurance Co. v. Clay, I97 Fed. 435, 436 (D.C.E.D.Ky. x9I2); Bell v. Louisville Board of Fire Underwriters, I46 Ky. 84I, I43 S.W. 388 (rgI2); State ex rel. Martin v. Howard, 97 Neb. 278, I47 N.W. 689 (1914). The last cited case upheld a statute permitting the establishment of maximum rates for surety and fidelity companies. See also REPORT OF MerRItT CoMamitreE, op. cit. supra note 5, at 50-51, commenting upon regulatory steps taken by Kansas, Texas, and Louisiana.

16 The validity of a Kentucky statute empowering an insurance board to fix fire insurance rates which were neither "unjust, unreasonable, inadequate or excessive" was sustained by a federal district court of Kentucky in 1912. Citizens Insurance Co. v. Clay, 197 Fed. 435 (D.C.E.D.Ky. 1912). Contra: American Surcty Co. v. Shallenberger, 183 Fed. 636 (C.C.D.Neb. rgro) (holding invalid a Nebraska law (Neb. Laws r 1909, c. 27) providing for regulation of rates of surety and fidelity companies).

${ }_{10} 233$ U. S. 389 (1914).

${ }^{10}$ The Superintendent's order directed the bureau companies writing fire insurance in Kansas to reduce their rates by $\mathrm{I} 2$ per cent. Id. at 397 . He was proceeding under a statute providing that "when the superintendent shall determine any rate is excessive or unreasonably high or not adequate to the safety or soundness of the company, he is authorized to direct the company to publish and file a higher or a lower rate, which shall be commensurate with the character of the risk; but in every case the rate shall be reasonable." Id. at 39r.

${ }^{17}$ New York in 1922 empowered its Insurance Superintendent to adjust any fire rate that was "excessive, inadequate, unjust or unreasonable." N. Y. INs. LAW I922, c. 460, \$14Ia.

${ }^{10}$ Kansas and New York statutes cited supra notes 16 and 17. 
whether fire rates were excessive came to be dependent in turn upon the reasonableness of the aggregate profits of the companies engaged in concerted rate-making. ${ }^{19}$

By I944, the year in which the South-Eastern Underwriters case ${ }^{20}$ was decided, there was a fairly crystallized pattern of fire rate regulation. Most of the states recognized company-organized fire insurance rating bureaus over which their commissioners had varying degrees of supervisory power. ${ }^{21}$ A majority of these states required filings of rates and rating schedules; eleven required all fire insurers to be members of a bureau; and two required that all stock fire insurers belong to a bureau. $^{22}$ Such remaining anti-compact laws as there were, had for the most part been tacitly repealed by statutes recognizing rating bureaus. ${ }^{23}$

\section{III}

\section{Early Casualty Rate Regulation}

In the casualty field before I944, there was no crystallized regulatory pattern as in fire insurance. Except in the field of workmen's compensation, most of the states did not subject casualty rates to any more pervasive regulation than prohibitions against discrimination. ${ }^{24}$ Not more than ten or so states required filing and approval of automobile insurance rates. ${ }^{25}$

The explanation for this difference between rate regulation in the fire and casualty fields lies in the fact that in the casualty field generally, and in the automobile line in particular, competition was the rule and not the exception. Roughly, only half

${ }^{19}$ A 1919 Arkansas statute empowered the insurance commissioner to order reduction of rates of stock fre insurance companies to keep their aggregate underwriting profit down to 5 per cent. During the litigation following the first reduction order (Bullion v. Aetna Insurance Co., I5I Ark. 519, 237 S.W. 7r6 (x922)), the Commissioner asked the N.C.I.C. for assistance in devising a proper method for computing underwriting profit. The so-called Commissioners' I92I Profit Formula was the result.

There have been several applications of this profit formula to the fire insurance business. The formula has, without exception, been applied only to limit the rates of stock fire insurance companies engaged in concerted rate making through rating bureaus. The reasonableness of their average aggregate profits has furnished the criterion for the determination of the propriety of their rates. Actna Insurance Co. v. Travis, I21 Kan. 802, 257 Pac. 337 (1926), I24 Kan. 350, 259 Pac. 1068 (1927); Actna Insurance Co. v. Hyde, 315 Mo. 113,285 S.W. 65 (1926); Aetna Insurance Company v. Commonwcalth, 160 Va. 698, 169 S.E. 859 (1933); Jordan v. American Eagle Fire Insurance Co., I69 F. 2d 281 (D.C. Cir. 1948).

The Commissioner's orders in those cases do not directly prescribe maximum rates, but that is their effect. The orders simply require that all bureau companies reduce their rates by a specified percentage or by an amount calculated to yield a reasonable aggregate profit, usually leaving to the companies' or bureaus' determination the application of the reduction by class of risk, subject of course to the Commissioner's approval. See the Bullion v. Aetna Insurance Co., Aetna Insurance Co. v. Commonwealth, and Jordan v. American Eagle Fire Insurance Co. cases, supra.

The Formula has been recently revised by the Fire and Marine Committee of the N.A.I.C., but it still is designed to apply only to fire insurance companies making rates in concert. No attempt was made "to deal with related problems found in other lines of insurance, in unusual methods of operation, or the problems of rate making by independent insurers." Report of the Fire and Marune Committee, Proceedings, National Association of Insurance Commissioners, 463 (8oth Sess. 1949).

${ }^{20}$ United States v. South-Eastern Underwriters Ass'n, 322 U. S. 533 (x944).

${ }^{21}$ See A Study of the Necessity and Form of State Regulation of Insurance (pamphlet prepared by the California Insurance Dep't, Jan. 29, I945).

22 Id. at 46 , Exhibit V.

${ }^{23} \mathrm{KuLP}$, op. cit. supra note 9, at 623 .

24 Id. at 622 .

${ }^{25} I d$. at 626,627 . 
of the automobile business in the United States was written by members of the two national rating bureaus, the National Bureau of Casualty Underwriters and the Mutual Casualty Insurance Rating Bureau.

Such was the insurance rate regulatory pattern at the time the South-Eastern Underwriters case was decided. That decision exposed rate making in concert to the penalties of the federal antitrust laws. Even though there was considerably more competition in casualty insurance than in fire, concerted rate making in the casualty field was subject to the same antitrust law sanctions.

The legislative alternatives available to the industry following the enactment of the McCarran $\mathrm{Act}^{2 \mathrm{~s}}$ are known to all. Proposals varied from empowering commissioners to prescribe the use of uniform rates for all carriers, to regulating only such rates as were made in concert. The statutory authorization of concerted rate making, subject to supervision of methods and practices therein, but with no control over the rates themselves, was deemed by most insurers who were members of bureaus to be insufficient to meet the requirements of the McCarran Act. This same method is now advanced as adequate, however, by some spokesmen for such companies, in connection with proposed legislation regulating agreements upon commissions to be paid producers. ${ }^{27}$

Independent companies and other members of the industry were divided in their views as to how far the proposed state legislation should go. All independent companies were united, however, in their adamant opposition to the formation of any legislative program which would necessitate uniformity of action, discourage competition, or tend to require rigid adherence to particular rating or operating methods. They were equally opposed to any program which would deprive them of freedom either to participate in joint rate making activities or not as they saw fit.

Out of the crucible of varying points of view, the Commissioners-All-Industry Bills appeared as a compromise. No one was completely satisfied with the result, but all subscribed to the following statement made by the Committee on Rates and Rate Making in reporting the bills to the National Association of Insurance Commissioners: $:^{28}$

The committee makes no claim that the proposed bills represent the ultimate or last word in rating bills. It is recognized that the science of rate regulation is a progressive one and that changes in thinking will occur as our experience and stock of knowledge increase.

\section{IV}

\section{The Commissioners-All-Industry BrLls}

The Commissioners-All-Industry Bills, products as their title implies of cooperative action between the insurance commissioners and the insurance industry, were

${ }^{20} 59$ STAT. 33 (I945), as amended, 6I STAT. 448 (1947), I5 U.S.C. \$\$IOII-IoI5 (Supp. I949), making the Sherman Act applicable to insurance "to the extent that such business is not regulated by State law."

27 The Weekly Underwriter, May I3, I950, p. III4, col. 2.

${ }^{28}$ Proceedings, N.A.I.C., 94 (77th Sess. 1946). 
designed to provide supervision of rate making in concert, and to require reasonable rates. They were also designed to preserve reasonable freedom to independents. The purpose section of the bills provided $:^{2 D}$

Nothing in this Act is intended ( $\mathrm{r}$ ) to prohibit or discourage reasonable competition, or (2) to prohibit, or encourage... uniformity in insurance rates, rating systems, rating plans or practices.

The bills contained express reservations designed to preserve the opportunity for independent operation. ${ }^{30}$ In addition, the bills afforded a great degree of flexibility with respect to the formation and operations of rating bureaus. ${ }^{31}$ There were limitations upon the rule making powers of bureaus-among them a requirement that any applicant be permitted to subscribe to bureau services on reasonable terms. ${ }^{32}$

The bills required that every insurer file the rates and rating plans to be used by it. ${ }^{33}$ But as first drafted, the Commissioners-All-Industry Bills would have imposed a most onerous and completely unnecessary burden upon independents. The drafts tentatively reported to the N. A. I. C. by the Committee on Rates and Rating Organizations contained the following filing requirements in section $4(a):^{\mathbf{3 4}}$

Every insurer shall file with the [commissioner] every manual of classifications, rules and rates, every rating plan and every modification of any of the foregoing which it proposes to use. Every such filing shall indicate the character and extent of the coverage contemplated and shall be accompanied by the information upon which the insurer supports the filing. A filing and supporting information shall be open to public inspection after the filing becomes effective.

This section apparently made mandatory the filing of supporting information completely without regard to what information, if any, was necessary for the determination of whether the rates in question met the rating law standard. The standard was, of course, reasonableness; rates were not to be inadequate, excessive, or unfairly discriminatory.

Spokesmen for some independent insurers moved at this juncture for important and necessary modification. It came in the form of an amendment to section $4(\mathrm{a})$,

${ }^{20}$ Casualty and Surety, and Fire, Marine and Inland Marine Rate Regulatory Bills, drafts of May I8, 1946, Proceedings, N.A.I.C., 397, 4 Io (77th Sess. 1946), as amended, Proceedings, N.A.1.C., 410 (78th Sess. 1947). See Explanatory Memorandum of Drafting Committee, I946 Proceedings, at 120.

${ }^{30}$ No insurer is required to become a member or subscriber of a rating organization. Sec. 4 (b). Insurers may not be required to record and report loss experience on a classification basis inconsistent with the rating systems filed by them. Sec. $1_{3}(2)$. Compilations of loss and expense experience are available to all insurers. Sec. $4(\mathrm{a})$.

${ }^{31}$ Any number of rating organizations may be licensed. The rules of a rating organization and their application to subscribers must be reasonable. No rating organization may adopt any rule which would prohibit or regulate the payment of dividends by insurers to their policyholders. Sec. 6 . Members or subscribers of rating organizations may deviate from rates filed by such organizations; they may adopt their own systems of expense provisions. Sec. 7. Members or subscribers may appeal to the Commissioner from actions or decisions of such organizations. Sec. 8.

${ }^{32}$ Sec. $6(\mathrm{~b})$ of bills cited supra note 29 .

${ }^{33} I d$. at $\$_{4}(\mathrm{a})$. The filing requirement may be satisfied by becoming a member or subscriber of a licensed rating organization. Sec. $4(\mathrm{~b})$.

34 Proceedings, N. A. I. C. Ir3 (77th Sess. 1946). 
adoption of which was recommended by the Conference Committee of the N. A. I. C. The amended section 4 (a) read: $:^{35}$

Every insurer shall file with the (commissioner) every manual of classifications, rules and rates, every rating plan and every modification of any of the foregoing which it proposes to use. Every such filing shall state the proposed effective date thereof, and shall indicate the character and extent of the coverage contemplated. When a filing is not accompanied by the information upon which the insurer supports such filing, and the (commissioner) does not have sufficient information to determine whether such filing meets the requirements of the Act, he may require such insurer to furnish the information upon which it supports such filing. Any filing may be supported by $(I)$ the experience or judgment of the insurer or rating organization making the filing, (2) the experience of other insurers or rating organizations, or (3) any other factors which the insurer or rating organization deems relevant. A fling and any supporting information shall be open to public inspection after the filing becomes effective.

Additional amendments were made to section 5 of the bills to make sure that the approval or disapproval of any new rating plans or systems would be dependent, not upon what most companies did, but upon the empirical test of whether the rates thus produced satisfied the rating standard. ${ }^{36}$ These bills, as amended, were then passed, with some variations, by virtually all of the states. ${ }^{37}$

\section{A. Meaning of Term "Excessive"}

The degree of competition may have an important bearing on the question of whether rates are reasonable or excessive. A brief examination of the relationship between the antitrust laws and affirmative rate regulation will enable us to establish with some accuracy the bearing of the competitive situation upon the rate reasonableness question.

The early state anti-compact laws had the same purpose as the Sherman Act-to bring about free and open competition. They were designed to prevent concerted price fixing and monopolizing by fire insurance companies. They were abandoned because they failed to bring about such free competition and because some concerted rate making activities were necessary and in the public interest. These state laws were, therefore, supplanted by statutes requiring supervision of concerted rate making activities and regulation of rates. Rate regulation was designed in part to curb the potential power of the group monopolies to charge excessive rates.

The Congress in enacting Public Law ${ }_{5}$ did not change this situation. The McCarran Act, among other things, simply exempts concerted rate making from the application of the Sherman Act so long as such activities are "regulated by state law."38 In recommending the passage of the bill, the House Judiciary Committee admonished that "competitive rates on a sound financial basis are in the public interest." 39

${ }^{35}$ Proceedings, N.A.I.C. 4 To (78th Sess. 1947). ${ }^{30} I d$. at $4 \mathrm{Ir}$.

${ }^{37}$ For tabulation of states, see Shield, Some Procedural and Administrative Questions Arising Under Laws Resulting From Public Law 15, 1949 Proceedings, A. B. A. Insurance Law Section 233, 247.

${ }^{38}$ Supra note 26.

${ }^{80}$ H. R. REP. No. 143, 79th Cong., Ist Sess. 670 (1945). 
Bearing in mind that regulation of rates was instituted to prevent the exercise of monopoly power by insurance companies acting in concert, and that it is only where a monopoly power is exercised that excessive rates can be charged, it is clear that rate supervisory authorities need not be concerned about excessiveness where there is competition. Competition does not permit excessive rates. That is the very economic theory upon which the Sherman Act and the anti-compact laws were based.

Obviously, rates filed by rating organizations require closer scrutiny than those of independents. There are no independents of monopoly size. They, therefore, lack the monopoly power which would enable them to charge excessive rates. They must meet competition which in itself is a much more effective regulator than any rating law.

Too, the degree of concern of supervisory bodies over rate filings by rating organizations might well differ state by state. In a state where bureau companies write all or a substantial portion of the business, the possibility of excessive rates is much greater than in a state where their writings are not substantial. For example, rate filings for automobile bodily injury and property damage insurance in a state like North Carolina should be scrutinized with much greater care than in a state like Iowa. In North Carolina there is only one rating organization, and membership therein is compulsory. ${ }^{40}$ In Iowa in 1948, the companies that are members of the National Bureau of Casualty Underwriters wrote approximately 15 per cent of the total automobile bodily injury and property damage premiums; most of the remaining 85 per cent was written by independent companies competing not only with the bureau companies but with each other. ${ }^{41}$ If the philosophy of the Sherman Act is sound, the danger of the North Carolina rates being excessive in the absence of regulation is substantial; but the danger of Iowa rates being so tainted is negligible.

There is another facet to this problem. In some states, members of some rating organizations compete on the basis of rates with members of other rating organizations as well as with independents. Where rates, whether made individually or in concert, are generally lower than the prevailing maximum rates in the territory, they cannot be excessive. It follows that such rates, filed by either rating organizations or independents, need be given less scrutiny than the maximum rates generally charged in the territory.

An examination of the California rating law will be helpful at this point. That statute, too, requires that "rates shall not be excessive," but defines "excessive" as follows: ${ }^{42}$

No rate shall be held to be excessive unless ( $x$ ) such rate is unreasonably high for the insurance provided and (2) a reasonable degree of competition does not exist in the area with respect to the classification to which such rate is applicable.

This definition simply spells out what is implicit in the word "excessive." It

${ }^{10}$ N. C. INs. Laws, Art. 25, \$58-247 (1945).

4I Facts and Figures of the Casualty Insurance Business (compiled December, 1949, by the National Bureau of Casualty Underwriters).

${ }^{42}$ CAI. INS. CODE, Art. 2, \$1852(a) (1947). 
is only where a monopoly power is exercised that excessive rates can be charged. This is the very premise upon which rate controls are based.

Most state insurance departments have recognized these principles. Unfortunately, however, a few have been inclined to subscribe to the notion that the term "excessive" is somehow dependent upon the individual filing company's profits. This reflects both a misunderstanding of the reasonableness standard of Section 3, and a failure to take account of the history and purposes of competitive rate regulation. Fortunately, this error has not manifested itself in official action. Some exposition of the meaning of "excessive" may prevent the possible further spread of this erroneous concept.

Rate regulation as such was instituted to regulate rates of individual natural monopolies which, by virtue of their monopoly status, had the power to charge exorbitant rates. ${ }^{43}$ Probably most of the present day rate regulatory laws are still directed at control of monopoly rates. There being no competition to keep the price down, the only effective limitation a rate supervising authority can place upon a monopoly's rates is the denial of those which would yield it an excessive return. ${ }^{\mathbf{4 4}}$ The test of rate reasonableness for monopolistic utilities has therefore come to depend upon the existence of a reasonable relation between earnings and investment value. ${ }^{45}$ The absence of "commercial limitations" of competition has necessitated this type of control. ${ }^{40}$

In regulating competitive as opposed to monopolistic rates, the standards for determining rate reasonableness are necessarily quite different. Suppose, for example, that the Interstate Commerce Commission, which has been charged since 1887 with the duty of seeing that railroad rates are "just and reasonable" and non-discriminatory, ${ }^{47}$ undertook to determine the reasonableness of a railroad rate for shipment

\footnotetext{
${ }^{4}$ Rates were first fixed by state statute. Validity of such statutes was upheld by the United States Supreme Court in 1877 , in Munn v. Illinois, 94 U. S. Ir3 (grain elevator rates), and the Granger Cases, 94 U. S. $155,164,179,180$ (railroad rates).

" See dissenting opinion of Justice Brandeis, St. Louis \& O'Fallon Ry. v. United States, 279 U. S. $46 \mathrm{r}, 536-537$ (1929).

"For instance, the Secretary of Agriculture, operating under a statute governing charges of stockyards and marketing agencies has the power to prescribe "just and reasonable" rates. 42 STAT. I66 (I92r), as amended, 7 U.S.C. \$2II (1946). Since such enterprises enjoy a monopoly and rating orders thus run to them individually, the Secretary's concern is simply to see that the rates prescribed for each company earns it a fair return. See Denver Union Stock Yards Co. v. United States, 2I F. Supp. 83 (D. Colo. 1937).

The Federal Power Commission regulates the rates of interstate electric energy and natural gas, which must be "just and reasonable." 49 STAT. 85I (I935), I6 U.S.C. \$824d (1946); 52 STAT. 822 (I938), 15 U.S.C. $\$ 717 c$ (1946). The statutes contain cost standards which alone are of concern to the Commission in judging reasonableness of rates, and, since the Commission deals solely with monopolistic utilities, its rate orders are individually applied. Federal Power Commission v. Natural Gas Pipeline Co., 315 U. S. 575 (1942); Federal Power Commission v. Hope Natural Gas Co., 320 U. S. 591 (r944). See analysis of federal regulation in Blachly, The Role of Smyth v. Ames in Federal Rate Regulation, $33 \mathrm{~V}_{\mathrm{A}}$. L. REv. I4I (1947).

${ }^{4}$ See note 44 supra.

47 The Act to Regulate Commerce, now the Interstate Commerce Act, was passed in 1887. 24 Stat. 379 (1887), as amended, 49 U.S.C. I et seq. (Supp. 1948). It requires that all charges be "just and reasonable"; discriminatory rates and rebates are made unlawful. Every carrier is required to file a schedule of rates which, unless found unreasonable by the Commission after a hearing, have the force
} 
of a commodity from New York to New Orleans. Would the Commission determine whether the rate was reasonable by reference to the rate of return of the road? Of course not. The Commission, as a practical matter, would look to the rates charged for the same or similar services by competing carriers, e.g., other railroads, steamship, or motor carriers. ${ }^{48}$ To find whether the rate in question was reasonable, they would determine the value of the service to the public by reference to open market criteria. ${ }^{49}$ In a competitive market there is no better practicable basis for determining whether the challenged rate is reasonable or excessive.

Both the Interstate Commerce Commission and reviewing courts long ago rejected the argument that the reasonableness of a competing carrier's rates was dependent upon its profits. ${ }^{.0}$ Where rates of a carrier do not exceed those charged by competitors for the same or similar services, they are ipso facto reasonable. Favorably situated carriers are free to earn whatever profits they can from such

of statutory rates. It lies within the exclusive province of the Commission to determine the reasonableness of the filed rate; while the act grants shippers the right to recover damages for unreasonable charges, the right of action does not accrue until the rate has been determined to be unreasonable by the Commission. Keogh v. Chicago \& N.W. Ry., 260 U. S. I56 (I922).

${ }^{* 8}$ See United States v. Northern Pacific Ry., 288 U. S. 490 (1933); Virginian Ry. v. United States, 272 U. S. 658 (1926); Louisville \& Nashville R.R. v. United States, 238 U. S. I (1915); Hooker v. I.C.C., I88 Fed. 242 (Com. Ct. I9II), rev'd on other grounds, 225 U. S. 302 (I912); R.F.C. v. Alabama Great Southern R.R., No. 29945, I.C.C. (1950); Miami Bottled Gas, Inc. v. Abilene So. Ry., 274 I.C.C. 6 (1949).

The adoption of this view by state commerce commissions, whose statutes were patterned after the Interstate Commerce Act, has been uniformly approved by state courts. Illinois Central R.R. v. Illinois Commerce Commission, 359 Ill. 563, I95 N.E. 32 (1935); Hocking Valley Ry. v. Public Utilitics Commission, II7 Ohio St. 304,158 N.E. 648 (xg27); Southern Ry. v. Hunt, 42 Ind. App. 90, 83 N.E. 72 I (1908); Atchison, T. \& S.F. Ry. v. State, 130 Okla. 263, 267 Pac. 253 (1928); Great Northern Ry. v. Department of Public Works, I6I Wash. 29, 296 Pac. 142 (1931).

"O Blachly, The Role of Smyth v. Ames itt Federal Rate Regulation, 33 VA. L. Rev. 141, 151 (1947).

${ }^{50}$ In Board of Railroad Commissioners of Iowa v. Illinois Central R.R., 20 I.C.C. I8I (19II), the Commission, in holding bridge tolls reasonable, stated at 186 : "But the fact that the net revenues of the Illinois Central from its ownership of the bridge, when so estimated, may be greater than the returns on ordinary business enterprises is not sufficient in itself to justify a holding that the bridge tolls are excessive. ... The net revenues have an undoubted and often an important bearing upon the question of the reasonableness of rates, but the value of the service to the shipper and the other elements so often referred to as entering into the reasonableness of rates must also be taken into consideration. ... . So also the fact that the net earnings of a carrier may be large does not of itself justify us in fixing a rate at less than is reasonable for the service, all other things being considered."

In Hooker v. Interstate Commerce Commission, 188 Fed. 242 (Com. Ct. I9Ir), rev'd on other grounds, 225 U. S. 302 (I912), shippers contested an order of the Commission fixing new maximum rates, and asserted that the newly promulgated rates were excessive as to one of the carriers because of its high profits. In upholding the Commission's order, the court stated: "It appears from the findings of the Commission that it has always refused in the consideration of the reasonableness of a ratc or rates to consider only the particular carrier making the same by itself, but on the contrary has always considered the rates in a particular territory or the rates of other carriers to be affected by the change of the particular rate or rates in question; ... While earnings may be considered in the fixing of a reasonable rate to be charged by a carrier for the transportation of freight, rates necessarily cannot be bascd upon earnings alone. This is made clearly to appear when we consider that a just and reasonable rate is one which is just to the carrier and to the shipper. It is a rate which iyields to the carrier a fair return upon the value of the property employed in the public service, and it is a rate which is fair to the shipper for the service rendered; and when this rate is established, if it results in large profits to the carrier, the carrier is fortunate in its business, and if it results in a loss of earning power so that the business of the carrier is unprofitable, the carrier is unfortunate." Id. at 251-253. 
reasonable rates. This is reflected in the great disparity in earnings of the various competing roads. ${ }^{\text {.1 }}$

We have already seen that the tendency of fire insurance companies to combine gave them, through their combinations, a monopoly power similar to that enjoyed by a single or natural monopoly. Legislative concern over the power of such combinations to charge excessive rates was the moving cause for state regulation, first by way of anti-compact statutes, and second, when that approach failed, through affirmative rate controls. Because these combinations enjoyed an almost complete monopoly power, there developed in some states controls over the aggregate profits of the group monopoly. The aggregate profit controlling device was designed to prevent this combination from exercising its monopoly power to charge exorbitant rates; it has never been applied to limit profits of any insurers except those acting in concert and charging what are marketwise maximum rates. ${ }^{52}$

But it must be remembered that although aggregate profit controls over concertedly made rates may be a reasonable device in the fire business by reason of the absence of substantial competition, the same rule is entirely inappropriate to the casualty field where competition has always been prevalent.

The existence of a "zone of reasonableness" has always been recognized under insurance as well as other types of rate regulation. ${ }^{53}$ This zone is circumscribed by

E1 The following table shows the 1948 rates of return for several railroads in the various regions in which they are grouped by the Interstate Commerce Commission:

$\begin{array}{cc}\text { EAilroad } \\ \text { EASTERN DISTRICT } & \begin{array}{c}\text { Rate of } \\ \text { Return }\end{array}\end{array}$

Bangor \& Aroostook.............. 7.94\%

Boston \& Maine. . . . . . . . . . . . . . 3.09

New York, New Haven \& Hartford...... 2.67 (Great Lakes Region)

Delaware, Lackawanna \& Western...... 4.15\%

Detroit \& Toledo Shore line........... 44.57

Erie Railroad................... 5.87

Lehigh \& New England............ 4.43

Lehigh Valley................... 4.74

New York Central................ 2.21

WESTERN DISTRICT

(Central Western Region)

Atchison Topeka \& Santa Fe......... 7.19\%

Chicago Burlington \& Quincy......... 5.43

Denver \& Rio Grande Western........ 9.57

Southern Pacific................... 4.66

Union Pacific.................. 5.81

Western Pacific.................. 3.46

SOUTHERN DISTRICT

(Southern Region)

Cincinnati, New Orleans \& Texas Pacific. . 9.73\%

Gulf, Mobile \& Ohio.............. 4.80

Illinois Central.................... 4.96

New Orleans \& Northeastern........... 44.23

Seaboard Airline................ 5.53

Southern Railway............... 5.66

In making the above computations the net investment figures were taken from the I.C.C. exhibits Nos. $I$ and 37 in Ex Parte No. I68, Increased Freight Rates, I948, 272 I.C.C. 695 (1948). Net operating income figures were taken from Preliminary Abstract of Railway Statistics for 1948 , published by the I.C.C.

62 Sce note ig supra.

53 That there is a zone of reasonableness is implicit in the wording of the rating standard in Section 3 requiring that rates be not "excessive, inadequate or unfairly discriminatory." In the Kansas statute held valid in German Alliance Insurance Co. v. Lewis, 233 U. S. 389 (I9I4), the rating standard required that rates be not "excessive or unreasonably high, and adequate to the safety or soundness of the company." There was an added proviso that "in every case the rate shall be reasonable." This section is quoted in full in note I6 supra. The New York rating law, passed in 1922, provided that the Superintendent might adjust any fire rate that was "excessive, inadequate, unjust or unreasonable." N.Y. INs. LAw 1922 c. $460, \$ 14$ I-a. "Unjust" and "unreasonable" obviously meant something more than "excessive" and "inadequate."

The rating standard of the Oklahoma insurance law, interpreted in American Druggists' Fire Ins. 
the terms "excessive" and "inadequate." Thus, where an independent insurer charged rates which were less than those charged by the group monopoly, its rates were held to be ipso facto reasonable and not excessive. ${ }^{54}$ In other words, the reasonableness of competitive rates for insurers, as for carriers under the Interstate Commerce Act, was determined by comparison with rates for similar services already established as reasonable. This rule simply acknowledged that where competition existed it was in itself the best rate regulator, and that a rate which was less than the prevailing maximum rate in the market could not be excessive.

Certainly, in the light of these precedents, there is no ground for the assertion that under the new rating laws the reasonableness of rates of independent insurers is dependent upon their individual rates of profit. Like the Interstate Commerce Act, the rating laws are designed to regulate rates, not company profits.

There is an additional reason why the rating laws cannot be interpreted so as to make the reasonableness of an independent company's rates dependent upon its individual profits rather than competitive market standards. An essential purpose of the rating laws is to preserve the freedom to compete. There is no compulsion on a company, however, to compete on the basis of price. An insurer has a right to become a subscriber to a rating bureau. In the event it does, it must use bureau rates unless it applies for and receives permission to deviate therefrom. A commissioner has no power to compel deviations. There can be no doubt, therefore, of the freedom of any insurer to charge bureau rates as a matter of right regardless of its profits.

It follows that a commissioner has no power to disapprove the rates of an insurer not a member of or subscriber to a rating bureau because the profits of such company do not happen to strike him as "reasonable." Such a construction of the statute, which would compel Company $A$, an independent company, to reduce its rates while Company $B$, a bureau company, possibly earning more than $A$, could continue to charge the higher bureau rates, would be such an arbitrary and unreasonable classification as to deprive Company $\mathrm{A}$ of equal protection of the laws. ${ }^{.5}$ Obvi-

Co. v. State Insurance Board of Oklahoma, I 84 Okla. 66, 84 P. $2 \mathrm{~d} 6 \mathrm{I}_{4}$ (1938), discussed infra note 54, read substantially like that of the Kansas rating law in German Alliance Insurance Co. v. Lewis, stupra.

Cf. Missouri ex rel. Southwestern Bell Tel. Co. v. Public Service Commission, 262 U. S. 276, 296 (1923); United States v. Chicago M., St. P., \& P. R. Co., 294 U. S. 499 (x934); Wichita Gas Co. v. Public Service Commission of Kansas, 2 F. Supp. 792, 799 (D. C. Kan. r933); Wisconsin Tel. Co. v. Public Service Commission, 132 Wis. 274, 287 N.W. 122, I 49 (1939).

54 American Druggists' Fire Ins. Co. v. State Insurance Board of Oklahoma, I84 Ok:1a. 66, 84 P. 2d $6 \mathrm{I}_{4}$ ( 1938 ). In that case an insurer appealed from an order denying it the right to continue its plan of a uniform 25 per cent reduction from bureau rates. The Oklahoma rating law provided that "when said board shall determine that any rate made by such insurance company in this state is excessive or unreasonably high, or that said rate is inadequate to the safety or soundness of the company granting the same, it is authorized to direct said company to fle a higher or lower rate, commensurate with the risk, but in every case the rate shall be reasonable." Id. at 69, 84 P. $2 \mathrm{~d} 6 \mathrm{r} 7$.

In its discussion of whether the proposed rates were reasonable, the court stated: "Inasmuch as the objection is to the proposed reduction in the manual rates, there can be no contention that the rate is excessive or unreasonably high. The only question is whether it is inadequate." The court then concluded that the rates were not inadequate in view of the company's financial position. Ill. at 70, 84 P. $2 \mathrm{~d}$ at $6 \mathrm{I} 8$.

${ }^{85}$ Cotting v. Kansas City Stock Yards Co., I83 U. S. 79 (I90I); Western Ry. of Alabama v. Railroad Commission, 197 Fed. 954 (D.C.M.D.Ala. 1912). 
ously the rating laws were not designed to operate in an unconstitutional manner.

It is no answer to point out that if the independent company enjoying the larger profit was a member or subscriber of a rating organization, the effect would be to reduce the rates of all members and subscribers and the aggregate profits of such companies. In the first place, if the larger profit of the individual company was the result of a more favorable loss experience, the affiliation of such company with a rating organization would undoubtedly result in only an insignificant overall rate reduction, and the profit of such individual company would not be appreciably reduced. The ultimate earned profit of such company would still be considerably in excess of the profit that would have resulted to it, if it had remained an independent, and was compelled to reduce its rates to a figure which would produce a profit not in excess of that earned by bureau companies. And it must be remembered that if the larger profit of the independent company was the result of a more favorable expense factor and economical and efficient management, its affiliation with a rating organization would not result in any reduction in its profits, or in the aggregate profits or the overall rates of the other companies comprising such organization.

Under a statute not designed to discourage competition, an interpretation penalizing those injecting price competition into the insurance business obviously would have that undesired effect. If companies charging less than bureau rates were compelled to reduce them still further, they would soon lose their incentive to compete on the basis of rates. Their tendency would be to relax efficient and economic management, and this tendency, in turn, would inevitably reflect itself in higher expenses. As a result, their rates would soon not only equal the rates previously sought to be charged but would eventually exceed them and reach a state of equality with those of their competitors; at this point rate uniformity, an unintended result of the rating laws, would become a consummated fact.

The Interstate Commerce Commission has always sought to foster efficiency of management. ${ }^{56}$ A contrary course in administering the insurance rating laws, which would deprive management of the will to serve the public efficiently and economically, might well spell the end of state regulation.

\section{B. Meaning of Term "Inadequate"}

As we have already seen, the term "inadequate" marks the lower boundary of the zone of reasonableness for insurance rates. Inadequate rates was one of the purely secondary evils at which early insurance rate regulation was aimed. In the

so The admonition of the Interstate Commerce Commission in Advances in Rates-Western Case, 20 I.C.C. 307 ( $191 \mathrm{I}$ ), is as poignantly applicable today to insurance regulation as it was to the regulation of common carriers in Igri. The Commission stated: "Moreover, some method must be found under which a carrier by its own efficiency of management shall profit. A premium must be put upon efficiency in the operation of the American railroad. . . Society should not take from the wisely managed railroad the benefits which flow from the foresight, skill, and planned cooperation of its working force. We may ruin our railroads by permitting them to impose each new burden of obligation upon the shipper. And we can make no less sure of their economic destruction by taking from them what is theirs by right of efficiency of operation-the elimination of false motion, of unneeded effort, and the conservation of labor and materials." Id. at 334 . 
consideration of whether a rate is inadequate, the rates of both independent and bureau companies stand in the same position.

It must be remembered that the statistical basis of a rate affords only one standard for testing its adequacy. Insurance departments have other rate testing data available. First, there is the overall compiled statistical loss and expense data from both bureau and independent companies, filed with each insurance department annually under the requirements of section $\mathrm{I}_{3}$ of the rating acts. Second, there are the annual statements of each company on file with each department disclosing all details with regard to the company's financial condition, and containing, among other things, exhibits of premiums written, losses paid, and the complete underwriting experience. Third, there are the filed periodic convention examination reports.

An insurance supervisory body may well fulfill its duty of determining whether a rate is adequate by looking at the general financial history of the particular independent company, instead of subjecting it to what is really an impossible requirement-the demonstration that each rate is computed with mathematical and scientific accuracy.

Experience has demonstrated that the possibility that rates of either independent or bureau companies will be inadequate is a very unlikely one. Profit is still the objective towards which all American companies, including those engaged in insurance, strive. The history of the insurance business in this country does not indicate any grave danger that insurance protection is, or will be, afforded for less than cost. Of course, there have been insurance failures, but financial failures were not peculiar to the insurance business. The strictest regulation of both national and state banking institutions did not prevent huge losses to depositors. The business of insurance presents a far better record, particularly when it is recalled that casualty rate regulation is of comparatively recent origin. The premium volume of the handful of insurers placed in liquidation during the last decade was an infinitesimal percentage of the aggregate countrywide casualty premium volume. Furthermore, such failures were in most instances due to causes other than inadequate rates.

Here again, the California rating law furnishes us assistance. It defines the term "inadequate" as follows: $: 77$

No rate shall be held to be inadequate unless ( $I$ ) such rate is unreasonably low for the msurance provided and (2) the continued use of such rate endangers the solvency of the insurer using the same, or unless (3) such rate is unreasonably low for the insurance provided and the use of such rate by the insurer using same has, or if continued will have, the effect of destroying competition or creating a monopoly.

This definition is consistent with the philosophy and the proper interpretation of the Commissioners-All-Industry Rating Laws. A rate must be substantially and demonstrably unremunerative, and the solvency of the company employing it must be endangered, before it can be considered inadequate. The use of unremunerative rates for the purpose of waging rate wars or obtaining monopoly control is also

${ }^{47}$ See note 42 supra. 
enough to condemn such rates. Support for this interpretation of the term "inadequate" can be found in the early insurance rate regulation which was aimed at those competitive abuses. 58

The author does not mean to imply that insurance departments should never require explanation or data with regard to the adequacy of a filed rate. If it is patently inadequate, or if, after reviewing the financial history of the filing company, the department has grave uncertainties as to adequacy, further data should be demanded. However, with respect to many filings no additional data is requisite. The industry should not be subjected to the expense and inconvenience of preparing and furnishing such data in connection with every filing.

\section{Supporting Information}

Section I3 $_{3}(\mathrm{a})$ of the Rating Acts requires each insurer to record and report its loss and countrywide expense experience in order that the commissioners can determine whether rating systems comply with the reasonableness standards of Section 3. This data is compiled by rating organizations or other agencies pursuant to rules and statistical plans promulgated by the commissioners. Thus, the insurance departments are accumulating very comprehensive classified data which furnish a very satisfactory aid for determining readily the reasonableness of rate filings.

Only when a commissioner does not have on file sufficient information to enable him to determine the reasonableness of a filed rate, is he authorized by the statutes to require supporting information. One might suppose that the amendment to Section 4 (a) would have settled that. There has developed, however, an unfortunate trend on the part of insurance departments to request statistical supporting information as a matter of course, without first making the necessary determination that there is not already on file sufficient data to support the filed rates.

This is a somewhat understandable oversight. Statistics are fascinating things, and it is easy to become statistic-minded. Normal curiosity leads us all to thirst for more information than we will ever conceivably need.

But when these foibles are translated into mountains of unnecessary and expensive work, it is only human, too, for the suppliers-elect of such data to be moved to impatience. Only recently one insurance department, by promulgating "suggestions," has fallen into the error of implying that supporting information should accompany all rate filings, even though its rating act, unlike the Commissioners-AllIndustry Bills, makes no provision whatever for the furnishing of such information. ${ }^{\text {s9 }}$

It is to be remembered that the rating standard requires that a filed rate be neither inadequate, excessive, nor unfairly discriminatory. Suppose, for example, that an independent filed rates representing a flat, across-the-board reduction from bureau rates. In that situation, all a commissioner would need to know to determine whether the rating standard was met could be gleaned from the bureau filing and the company's profit and loss statements. If the reduction was less percentage-wise

${ }^{88}$ See notes 7 and 9 supra.

${ }^{50}$ Filing Procedure, State Insurance Board of Oklahoma Bulletin, April 3, 1950. (See Okla. Sess. Laws, H.B. 359 (1949)). 
than the company's percentage of underwriting profit; the new rates could scarcely be -unremunerative and dangerous to the company's solvency; they could not, therefore, be inadequate. Since the reduction from established reasonable rates was uniform, the filed rates could not be unfairly discriminatory. Because they were less than other rates already approved as non-excessive for the territory involved, they could not be excessive.

.This is but one of the many situations in which information already on file affords a completely adequate supporting basis for new rate filings. Other examples have been cited, supra, in the discussion of the meaning of the terms "excessive" and "inadequate." If it is borne in mind that the purpose of rate filings is simply to enable supervisory officials to test rates by the reasonableness standard of Section 3, much needless effort in the treatment of independent filings can be avoided. The reasonableness of practically all such rates can be established by merely comparing them with rates already on file and established as reasonable. There is a timehonored precedent for this practice of comparison in the administrative record of the Interstate Commerce Commission. That body has long determined the reasonableness of an individual carrier's rates by comparing them with those charged for the same or substantially similar services by other carriers competing for the traffic. ${ }^{00}$

Supporting information may consist of (I) experience or judgment of the insurer," (2) interpretation of statistical data relied on, (3) experience of other insurers or rating organizations, or (4) any other relevant factors. These supporting factors were spelled out in the statute for the very purpose of making unnecessary the filing of detailed statistical supporting information where there was sufficient information on file to support filed rates, or where rates were based not on statistics büt judgment. Their flexibility makes it emphatically clear that it was not the purpose of the rate laws to limit the exercise of judgment of professional risk bearers by slide-rule controls. Where there is no experience on which reliable statistics can be based, the trained and experienced judgment of acknowledged underwriting experts is enough to support a filing. When this ceases to be true insurance will have ceased to grow. But that growth cannot be stunted under the rating law because Section 4(a) forbids it. The legislative command is for flexible administration that will not stifle competition by making it cheaper and easier to conform than to compete.

There seems to have developed a feeling on the part of some insurance supervisory bodies that to avoid possible congressional or state legislative criticism, it is necessary for their files to disclose, with respect to each filing, that they requested and received mathematical computations demonstrating the accuracy of filed rates. The writer has endeavored to point out that such statistical information in connection with every filing was not contemplated by the Commissioners-All-Industry Rating Acts and is frequently unnecessary. No group of companies has extended any greater cooperation to insurance departments, assumed more burdens to preserve

\footnotetext{
${ }^{\circ 0}$ See note 48 supra.
} 
state regulation, or been more understanding of the problems of insurance supervisors than independent companies. Insurance departments, too, have exhibited to a marked degree their understanding of the problems of independent companies and the industry as a whole. It is essential, however, that they also realize that an insurance department may adequately satisfy any legislative investigation by having its files disclose, in appropriate instances, that a rate has been reviewed and found to meet the standards in that (I) it does not exceed rates theretofore approved as reasonable, (2) is not inadequate in the light of the financial history of the filing company, and (3) is not unfairly discriminatory. Attempts on the other hand to require companies to file statistical computations in connection with all filings may so burden management as to endanger state regulation.

\section{$\mathrm{V}$}

\section{CoNCLUSION}

It is too early to make any conclusive judgments as to the success or failure of the new rating laws and their administration. Any regulation such as that contemplated by those laws, of course, requires additional work and some inconveniences to independent companies. But that is not a matter of great importance to the public so long as it does not bring about significant increases in the cost of insurance.

That is not to say, however, that the imposition upon these companies of quite unnecessary inconveniences and burdens will not become a matter of public concern. Such an administration, coupled with its deterring effect on the will to compete, could have a disastrous effect on competition in the insurance business. Since the public interest lies in the maintenance of competition, such an eventuality would make the undertaking of a new approach to the problem inevitable.

It is to be hoped, however, that such action will be unnecessary. If both the industry and the insurance commissioners will weigh their actions carefully, in the light of the purposes of the rating laws, and be ever conscious of the necessity for fostering competition, there is every probability that the present rate regulatory program will be successful, that state supervision will be preserved, and that the industry may face the future confident of even greater achievement. 